JURNAL KETAHANAN NASIONAL

Vol. 26, No. 1, April 2020, Hal 108-131

DOI:http://dx.doi.org/ 10.22146/jkn.52823

ISSN:0853-9340(Print), ISSN:2527-9688(Online)

Online sejak 28 Desember 2015 di :http://jurnal.ugm.ac.id/JKN

VOLUME 26

No. 1, April 2020

Halaman 108-131

\title{
Strategi Pemberdayaan Wilayah Pesisir Dalam Menghadapi Bencana Tsunami Serta Implikasinya Terhadap Ketahanan Wilayah (Studi di Desa Bulakan, Kecamatan Cinangka, Kabupaten Serang, Banten)
}

\author{
Syaiful Anwar \\ Universitas Pertahanan, Jakarta, Indonesia \\ email: syaiful.anwar@idu.ac.id \\ Agus Winarna \\ Universitas Pertahanan, Jakarta, Indonesia \\ email: aguswin@idu.ac.id \\ Priyanto \\ Universitas Pertahanan, Jakarta, Indonesia \\ email: priyanto@idu.ac.id
}

\begin{abstract}
Serang Regency in Banten Province is a multi-prone area of natural disaster, with the greatest potential disasters particularly like floods, landslides, earthquakes, tidal waves, tsunamis, and abrasion. At the time of the Banten tsunami at December 2018, Bulakan Village, Cinangka Subdistrict, Serang Regency was a tsunami affected area that was classified as quite severe. Natural disasters are real threats with non-military threats.The role of relevant ministries/government institutions as the main element in non-military defense also needs attention. The aim of this study is to find the root of the problems and also the solutions related to non-military defense in confronting the real threat in the form of a tsunami disaster that struck the Serang Regency. This research is using a qualitative method supported by the case-study method. All the information obtained from the defined informants was analyzed by qualitative analysis technique. This research also aims to analyze the implementation of coastal area empowerment strategies and institutional synergy mechanism implemented at Bulakan Vilage, Cinangka Subdistrict, Serang Regency, Banten Province.The results showed that the empowerment of coastal areas in the form of institutional synergy in Serang District was carried out with a tsunami disaster management plan based on empowerment of coastal areas such as the development of coastal community disaster awareness, and compiling sustainable plans for a tsunami disaster. Some factors that influence the implementation of the coastal areas empowering strategy in Serang Regency in facing the tsunami disaster are community supports and good communication among the stakeholders.
\end{abstract}

Keywords: Empowerment, Coastal Areas, Tsunami, Serang, Regional Resilience, Synergy.

\begin{abstract}
ABSTRAK
Kabupaten Serang di Provinsi Banten merupakan wilayah multirawan bencana, dengan potensi bencana terbesar yang meliputi banjir, tanah longsor, gempa, gelombang pasang, tsunami, dan abrasi. Pada saat tsunami yang menerjang Selat Sunda pada Desember 2018 lalu, Desa Bulakan, Kecamatan Cinangka, Kabupaten Serang merupakan daerah terdampak tsunami yang tergolong cukup parah. Bencana alam merupakan ancaman nyata berdimensi ancaman
\end{abstract}


Syaiful Anwar, Agus Winarna, Priyanto -- Strategi Pemberdayaan Wilayah Pesisir Dalam Menghadapi Bencana Tsunami Serta Implikasinya Terhadap Ketahanan Wilayah

(Studi di Desa Bulakan, Kecamatan Cinangka, Kabupaten Serang, Banten)

nir-militer. Peran kementerian/ lembaga pemerintah terkait sebagai unsur utama dalam pertahanan nir-militer juga perlu mendapat perhatian, sehingga ditemukan akar permasalahan dan solusi terkait pertahanan nir-militer dalam menghadapi anacaman nyata berupa bencana tsunami yang melanda wilayah Kabupaten Serang. Penelitian ini menerapkan metode kualitatif yang didukung oleh metode penelitian studi kasus. Informasi yang didapatkan dari para narasumber yang dituju selanjutnya dibahas dengan menerapkan teknik analisis kualitatif. Penelitian ini bertujuan menganalisis implementasi strategi pemberdayaan wilayah pesisir dan mekanisme sinergitas kelembagaan yang dilaksanakan di wilayah Desa Bulakan, Kecamatan Cinangka, Kabupaten Serang, Provinsi Banten. Hasil dari kajian ini memperlihatkan bahwa pemberdayaan wilayah pesisir di Desa Bulakan dalam bentuk sinergitas kelembagaan di Kabupaten Serang dilakukan dengan rencana aksi penanggulangan bencana tsunami berbasis pemberdayaan wilayah pesisir yang meliputi pembinaan kesadaran bencana masyarakat pesisir, dan menyusun rencana simulasi bencana tsunami berkelanjutan. Faktor-faktor yang mempengaruhi terselenggaranya strategi pemberdayaan wilayah pesisir di wilayah Serang dalam menghadapi bencana tsunami adalah dukungan masyarakat dan komunikasi yang baik antara para pemangku kepentingan.

Kata Kunci: Pemberdayaan, Wilayah Pesisir, Tsunami, Serang, Ketahanan Wilayah, Sinergi.

\section{PENGANTAR}

Negara Kesatuan Republik Indonesia, seperti halnya banyak negara-negara lain di dunia, memiliki ancaman yang beragam, baik yang bersifat fisik maupun non-fisik, yang dapat dikategorikan sebagai ancaman militer maupun non-militer. Salah satu ancaman yang sering melanda bangsa dan negara Indonesia adalah yang datang dari alam. Bencana alam dikategorikan sebagai ancaman non-militer yang nyata dan lebih dominan jika dibandingkan dengan jenis ancaman lainnya. Secara umum, bencana dapat diartikan sebagai kejadian atau rangkaian kejadian peristiwa yang merusak dan mengganggu kehidupan dan penghidupan manusia yang disebabkan baik oleh unsur alam dan/atau unsur non alam, maupun unsur manusia, sehingga mengakibatkan timbulnya korban jiwa manusia, kerusakan pada alam, kerugianmaterial, dan dampak kejiwaan (Badan Nasional Penanggulangan Bencana, 2009).

Dalam beberapa tahun terakhir, serangkaian bencana alam berupa gempa dan tsunami telah melanda banyak wilayah di Indonesia, yang telah menelan korban jiwa hingga ratusan ribu orang. Salah satu bencana tsunami yang tergolong besar adalah yang terjadi pada tanggal 22 Desember 2018 di wilayah Provinsi Banten, yang disebabkan oleh gelombang pasang surut yang tidak normal, akibat dari letusan gunung berapi Anak Krakatau. Bencana tersebut mengakibatkan korban tewas mencapai 222 jiwa, korban luka 843 orang, dan orang hilang sebanyak 28 orang.

Kabupaten Serang merupakan salah satu daerah yang terkena dampak langsung tsunami Selat Sunda yang terjadi pada Desember 2018 lalu. Kecamatan Cinangka di Kabupaten Serang merupakan Kecamatan dengan tingkat kerugian terbesar akibat tsunami Selat Sunda 2018. Empat desa di wilayah Kecamatan Cinangka merupakan desa dengan tingkat kerugian terbesar yaitu Desa Karang Suraga, Desa Bulakan, Desa Umbul Tanjung, dan Desa Pasauran. Setidaknya 290 bangunan yang terdiri dari rumah pemukiman dan tempat usaha di keempat desa tersebut hancur ataupun tersapu terjangan ombak tsunami Selat Sunda (Serangkab.go.id).

Selain kerugian harta benda, Pemerintah Kabupaten Serang juga menderita kerugian finansial dari sektor pariwisata yang diperkirakan mencapai 25,81 miliar rupiah. 
Kerugian tersebut disebabkan oleh kerusakan bangunan hotel/villa dan fasilitas lainnya yang mencapai 10,66 miliar serta prediksi loss revenue akibat pembatalan reservasi pada libur natal dan tahun baru yang mencapai 15,15 miliar. Tsunami Selat Sunda juga mengakibatkan turunnya jumlah wisatawan baik wisatawan lokal maupun mancanegara, hal tersebut juga disebabkan karena tsunami juga mengakibatkan kerusakan akses jalan menuju obyek wisata di wilayah kabupaten Serang yang kebanyakan berupa obyek wisata pantai.

Dengan banyaknya jumlah korban dan kerugian yang diderita akibat bencana tsunami tersebut, maka dapat dikatakan bahwa upaya yang dilakukan oleh berbagai pihak terkait belum mencapai hasil seperti yang diinginkan. Bencana tsunami yang merupakan bagian dari ancaman nyata seharusnya sudah terwadahi dalam kegiatan sosialisasi tentang deteksi dini, tanggap bencana dan upaya kesiapsiagaan bencana melalui strategi pemberdayaan wilayah pesisir yang terintegrasi dengan melibatkan semua unsur kekuatan bangsa menghadapi ancaman nyata yang berdimensi ancaman nirmiliter berupa bencana alam, khususnya tsunami.

Hal tersebut tentunya menjadi permasalahan terkait belum optimalnya strategi yang diimplementasikan dalam menangani bencana alam yang dimaksud. Dengan demikian, maka permasalahan yang diangkat oleh peneliti adalah: 'Strategi Pemberdayaan Wilayah Pesisir Dalam Menghadapi Bencana Tsunami serta Implikasinya Terhadap Ketahanan Wilayah' di Desa Bulakan, Kecamatan Cinangka, Kabupaten Serang, Banten.

Berdasarkan permasalahan yang diuraikan pada bagian pengantar, selanjutnya penelitian ini memiliki tujuan sebagai berikut: (1) Menganalisis strategi pemberdayaan wilayah pesisir di wilayah Desa Bulakan, Kecamatan Cinangka, Kabupaten Serang; (2) Menganalisis implementasi strategi pemberdayaan wilayah pesisir Desa Bulakan, Kecamatan Cinangka, Kabupaten Serang dan implikasinya terhadap ketahanan wilayah; dan (3) Menganalisis faktor dominan yang mempengaruhi penerapan strategi pemberdayaan wilayah pesisir di Desa Bulakan, Kecamatan Cinangka, Kabupaten Serang dalam menghadapi bencana alam tsunami.

Penelitian ini diharapkan dapat memberikan manfaat secara akademis yaitu untuk memperkaya khazanah ilmu pengetahuan, khususnya dalam cabang ilmu pertahanan, dalam upaya pertahanan nirmiliter menghadapi ancaman bencana alam. Penelitian ini juga ditujukan untuk memberikan saran bagi stakeholder di lingkungan Pemerintah Kabupaten Serang, Provinsi Banten, dalam menghadapi ancaman nirmiliter berupa bencana alam.

Penelitian ini dilakukan di Desa Bulakan, Kecamatan Cinangka, Kabupaten Serang, Provinsi Banten. Desa Bulakan dipilih karena desa tersebut merupakan salah satu desa dengan dampak tsunami yang cukup parah. Namun belum ada informasi mengenai pemberdayaan wilayah pesisir dalam menghadapi bencana tsunami yang berimplikasi pada ketahanan wilayah. Penelitian ini merupakan penelitian kualitatif dengan metode studi kasus. Pengumpulan data dalam penelitian ini dilakukan dengan menggunakan metode wawancara, observasi, dan studi pustaka.

Dalam melakukan pembahasan terhadap hasil data empirik yang didapatkan di lapangan, 
Syaiful Anwar, Agus Winarna, Priyanto -- Strategi Pemberdayaan Wilayah Pesisir Dalam Menghadapi Bencana Tsunami Serta Implikasinya Terhadap Ketahanan Wilayah (Studi di Desa Bulakan, Kecamatan Cinangka, Kabupaten Serang, Banten)

peneliti menggunakan beberapa teori dan konsep, yakni teori strategi, teori implementasi, dan konsep pemberdayaan wilayah pertahanan (Dawilhan), serta konsep ketahanan nasional Indonesia. Teori impelementasi mengacu kepada berbagai pandangan dari Pressman dan Wildavsky (1973:13), Tornanatzky dan Johnson dalam Subandijah (1996:305), Harsono (2002:67), dan Setiawan (2004:39). Dari berbagai pendapat tersebut, maka peneliti selanjutnya dapat menetapkan bahwa implementasi merupakan tahapan dalam melengkapi dan memenuhi pencapaian tujuan dengan melaksanakan interaksi aktivitas tujuan, tindakan, dan sistim birokrasi yang efektif dalam rangka kesempurnaan suatu program.

Teori strategi yang digunakan adalah teori yang disampaikan oleh Anthony, Parrewe dan Kacmar (1999), yang mendefinisikan strategi sebagai formulasi dari misi dan tujuan suatu institusi, yang di dalamnya juga termasuk rencana aksi untuk mencapai sasaran yang ditetapkan,dan dengan secara eksplisit memperhitungkan berbagai kondisi kompetisi dan pengaruh-pengaruh kekuatan di luar institusi, yang secara langsung atau tidak langsung memberikan pengaruh signifikan terhadap kelangsungan institusi tersebut (Nainggolan, 2008). Penerapan teori strategi ini sangat mendasari pelaksanaan penelitian tentang pertahanan nir-militer di wilayah Serang.

Konsep tentang Dawilhan menyebutkan bahwa kegiatan ini dilakukan dalam rangka meningkatkan kemampuan pertahanan, melalui pembinaan potensi nasional, dalam rangka membantu pemerintah. Adapun tujuan pemberdayaan tersebut adalah mensinergikan strategi instansi fungsional dalam membina berbagai sumber daya, yaitu manusia, sumber daya alam, sumber daya buatan, berbagai sarana dan prasarana, nilai-nilai, teknologi, dan anggaran, yang ditransformasi menjadi kekuatan kewilayahan yang tangguh untuk mendukung kepentingan pertahanan. Dawilhan dilakukan dengan memberdayakan lembaga fungsional dan membangun sistem perencanaan pembinaan, pembangunan potensi nasional, dan Dawilhan di daerah secara terencana dan berkesinambungan.

Konsep ketahanan nasional bangsa Indonesia dapat diartikan kondisi hidup dan kehidupan nasional yang harus senantiasa diwujudkan dan dibina secara terus-menerus secara sinergi. Dimulai dari lingkungan terkecil yaitu diri pribadi, keluarga, masyarakat, bangsa dan negara, dengan modal dasar keuletan dan ketangguhan yang mampu mengembangkan kekuatan nasional. Dengan singkat dapat dikatakan bahwa ketahanan nasional ialah kemampuan dan ketangguhan suatu bangsa untuk dapat menjamin kelangsungan hidupnya, menuju kejayaan bangsa dan negara. Hakekat Ketahanan Nasional Indonesia adalah keuletan dan ketangguhan bangsa yang mengandung kemampuan dan kekuatan nasional untuk dapat menjamin kelangsungan hidup bangsa dan negara dalam mencapai tujuan nasional.

Dalam penelitian ini, asumsi filosofis yang digunakan adalah konstruksi-sosial dan analisis kualitatif dengan didukung oleh metode penelitian studi kasus. Adapun untuk lokasi penelitian adalah di Kabupaten Serang, Provinsi Banten. Penelitian ini diawali dengan fenomena tentang bencana alam tsunami, sehingga Kementerian/ Lembaga sebagai institusi pemerintah seyogyanya mendukung tercapainya strategi pertahanan nir-militer tersebut. Dalam kajian ini, penelitimenggunakan metode studi kasus, dengan pertimbangan bahwa peneliti 
menyelidiki secara langsung ke wilayah Banten tentang program-program dan aktivitas yang berhubungan dengan strategi pertahanan nir-militer yang telah dilaksanakan. Teknik pengumpulan data dilakukan melalui teknik observasi, wawancara dan studi literatur. Data primer yang didapat bersumber dari perwakilan Kementerian Pertahanan di daerah, instansi militer beserta jajarannya, tokoh masyarakat di wilayah pesisir, Kepala Desa sampai dengan Bupati. Sedangkan data sekunder bersumber dari media massa, internet, dan lain-lain. Penelitian ini dilakukan mulai dari bulan Juni hingga bulan Oktober 2019. Sedangkan dalam hal pengujian keabasahan data, sebagaimana diungkapkan oleh Sugiyono (2015), bahwa untuk menuju keabsahan dan keterandalan data maka diperlukan trianggulasi yang terdiri dari trianggulasi metode, trianggulasi sumber, dan trianggulasi teori. Sedangkan dalam hal teknik analisis data, menurut Miles \& Huberman dalam Sugiyono (2015), bahwa analisis data yang digunakan oleh peneliti meliputi: data reduction, data display dan conclusion drawing/verification.

\section{PEMBAHASAN}

\section{Gambaran Umum Objek Penelitian}

Kabupaten Serang merupakan salah satu Kabupaten dari enam Kabupaten atau Kota di wilayah Provinsi Banten. Kabupaten ini terletak di sebelah ujung barat dari Pulau Jawa dan juga berperan sebagai penghubung antara Pulau Jawa dengan Pulau Sumatera. Letak dari Kabupaten Serang adalah pada koordinat $5^{0} 50^{\prime}$ sampai dengan $6^{0} 21^{\prime}$ Lintang Selatan dan $105^{\circ} 0^{\prime}$ sampai dengan $106^{\circ} 22^{\prime}$ Bujur Timur. Adapun bila ditarik garis dari utara ke selatan, maka jarak yang paling jauh adalah $60 \mathrm{~km}$ dan jika ditarik garis dari barat ke timur, maka jarak terjauhnya adalah $90 \mathrm{~km}$.
Secara administratif, Kabupaten Serang di sebelah Utara berbatasan dengan Laut Jawa, sebelah Timur berbatasan dengan Kabupaten Tangerang, sedangkan sisi sebelah baratnya berbatasan dengan Kota Cilegon dan Selat Sunda, dan batas selatannya bertemu dengan Kabupaten Lebak dan Kabupaten Pandeglang (Pemerintah Kabupaten Serang, 2018).

Luas tanah daratan dari Kabupaten Serang sekitar 173.409 Ha, yang terbagi atas 34 kecamatan, 354 desa, serta 20 kelurahan. Kabupaten Serang juga memiliki wilayah lautan, di mana di dalamnya terdapat 16 buah pulau besar dan kecil. Adapun pulau-pulau tersebut adalah Pulau Satu, Pulau Pamujan Besar, Pulau Pamujan Kecil, Pulau Tunda, Pulau Semut, Pulau Kubur, Pulau Lima, Pulau Gedang, Pulau Sangiang, Pulau Salira, Pulau Kali, Pulau Tarahan, Pulau Kemanisan, Pulau Cikatung, Pulau Panjang, dan Pulau Dua. Kecamatan Tirtayasa sampai Kecamatan Cinangka adalah wilayah dengan ketinggian yang paling rendah, sedangkan Gunung Karang merupakan wilayah yang tertinggi, dengan ketinggian 1.778 mdpl (meter di atas permukaan laut). Kabupaten Serang secara umum berada pada ketinggian kurang dari 500 mdpl, yang cakupannya sekitar 97,5\% (Pemerintah Kabupaten Serang, 2018).

Daerah Aliran Sungai (DAS) yang di dalamnya terdapat Satuan Wilayah Sungai (SWS), secara umum di wilayah kabupaten ini relatif tidak terlalu luas. Sungai-sungai yang ada di kabupaten ini pada umumnya tidak terlalu lebar (kurang dari $50 \mathrm{~m}$ ) dan tidak terlalu panjang (kurang dari $100 \mathrm{~km}$ panjangnya). Selain itu juga terdapat Daerah Pengelolaan Sungai (DPS), di mana satu atau beberapa DAS dikelola secara bersama, baik dalam proses perencanaan maupun pelaksanaannya, yang diselenggarakan dalam 
Syaiful Anwar, Agus Winarna, Priyanto -- Strategi Pemberdayaan Wilayah Pesisir Dalam Menghadapi Bencana Tsunami Serta Implikasinya Terhadap Ketahanan Wilayah (Studi di Desa Bulakan, Kecamatan Cinangka, Kabupaten Serang, Banten)

rangka penggunaan anggaran agar lebih efisien.

Sedangkan kondisi demografis di Kabupaten Serang dalam rilis BPS tahun 2018 menyebutkan bahwa penduduk Kabupaten Serang berjumlah 1.493.591 jiwa dengan rasio penduduk laki-laki berjumlah 757.089 jiwa dan penduduk perempuan berjumlah 736.502 jiwa. Kecamatan Cikande menjadi Kecamatan dengan jumlah penduduk terpadat dengan 97.774 jiwa. Sedangkan laju pertumbuhan penduduk di Kabupaten Serang rata-rata 1,31 persen per tahun (BPS Kabupaten Serang, 2018).

Desa Bulakan merupakan salah satu desa di Kecamatan Cinangka, Kabupaten Serang. Yang terletak pada koordinat Bujur $105^{\circ} .84$ dan koordinat Lintang $-6^{0} .19$. Desa Bulakan memiliki wilayah berupa pantai hingga dataran rendah dengan ketinggian 0-14 meter diatas permukaan laut. Masayarakat Desa Bulakan kebanyakan bermata pencaharian sebagai petani dan nelayan serta mengandalkan dari sektor pendukung pariwisata pantai (prodeskel.bantenprov. go.id). Pada saat terjadi tsunami yang menerjang Selat Sunda pada Desember 2018 lalu, Desa Bulakan dan Desa Karangsuarga merupakan dua desa terdampak langsung tsunami dengan jumlah korban dan kerugian paling parah. Setidaknya 39 rumah dan 251 warung/tempat usaha rusak karena diporak-porandakan gelombang tsunami. Sedangkan untuk korban jiwa 13 orang dinyatakan hilang dan 60 orang mengalami luka-luka.

\section{Potensi Bencana Tsunami di Kawasan Pesisir Kabupaten Serang}

Wilayah Provinsi Banten merupakan daerah dengan tingkat kerawanan bencana yang sangat tinggi, tidak terkecuali pada
Kabupaten Serang. Provinsi Banten secara geologis berdekatan dengan pertemuan lempeng tektonik Indian, Australian, dan Eurasian. Selain pertemuan lempeng IndoAustralia dan Eurasia, yang menjadi sumber potensi gempa bumi di sekitar wilayah Provinsi Banten adalah lempeng mikro Sunda. Terjadinya gempa di Banten pada umunya diakibatkan oleh beberapa zona lempeng mikro dan juga struktur seismogenik. Patahan normal terbanan yang merupakan bagian dari struktur seismik telah diidentifikasi berada di wilayah Serang. Wilayah di Provinsi Banten di mana gempa sering terjadi adalah di Tanjung Kait, Tanjung Alang-Alang, dan Pulau Panaitan, yang lokasinya berada di Selat Sunda. Wilayah daratan di mana sering terjadi gempa adalah di Taman Nasional Ujung Kulon, wilayah barat dari Kabupaten Pandeglang, dan wilayah yang masuk dalam kompleks pegunungan Halimun. Karena sebahagian wilayah tersebut juga merupakan wilayah konservasi hewan langka, maka gempa bumi tersebut juga berpotensi merusak ekosistem satwa dilindungi, termasuk satwa langka badak Jawa.

Banten juga memiliki gunung berapi aktif yaitu Gunung Anak Krakatau. Dengan demikian menyebabkan Provinsi Banten menjadi daerah rawan bencana gempa bumi, baik gempa bumi tektonik maupun gempa bumi vulkanik. Gempa tektonik maupun vulkanik akibat erupsi Gunung Anak Krakatau dapat menimbulkan potensi bencana tsunami. Bencana tsunami pernah melanda wilayah Banten dan Lampung pada tahun 1883 akibat erupsi gunung Krakatau yang menyebabkan tsunami setinggi 30 meter. Sedangkan tsunami yang terjadi pada 2018 lalu diakibatkan oleh longsoran Gunung Anak Krakatau di bagian barat daya seluas 64 ha yang mengakibatkan gelombang setinggi 0,9 meter. Daerah-daerah 
yang memiliki kerawanan dalam hal bencana alam jenis tsunami adalah pesisir yang elevasinya kurang dari 25 meter. Kabupaten Serang dengan yang memiliki wilayah topografis dari 0 meter di daerah pesisir, tentu akan terdampak bencana tsunami tersebut (Khifni Sulaiman, et.al. 2012). Peta potensi bencana tsunami di Kabupaten Serang dapat dilihat pada Gambar 1.

Pada saat terjadi bencana tsunami Selat Sunda yang menimpa Provinsi Banten dan Provinsi Lampung, data yang dirilis oleh Badan Nasional Penanggulangan Bencana (BNPB) di Kabupaten Serang terdapat tiga orang korban meninggal dunia, empat lukaluka dan dua orang masih dinyatakan hilang, sedangkan kerugian materiil yang ditimbulkan diantaranya jalan raya penghubung Serang-
Pandeglang putus akibat tsunami dan puluhan rumah di pesisir pantai ikut tersapu gelombang tsunami. Setidaknya di wilayah Kecamatan Cinangka, Kabupaten Serang, ada empat desa di wilayah tersebut mengalami kerusakan paling parah akibat tsunami. Keempat desa tersebut adalah : Karang Suraga, Bulakan, Umbul Tanjung dan Pasauran.

Selain potensi bencana gempa bumi dan tsunami, banjir juga merupakan potensi ancaman bencana yang kerap menghampiri wilayah Provinsi Banten, tak terkecuali Kabupaten Serang. Data dari BPBD Kabupaten Serang dari Januari hingga April 2019, telah terjadi 8 kasus banjir yang menimpa Kabupaten Serang. Bencana banjir tersebut dipengaruhi oleh beberapa faktor, yaitu: curah hujan tinggi, berkurangnya daya dukung lingkungan, dan

Gambar 1

Peta Potensi Tsunami di Wilayah Serang, Banten

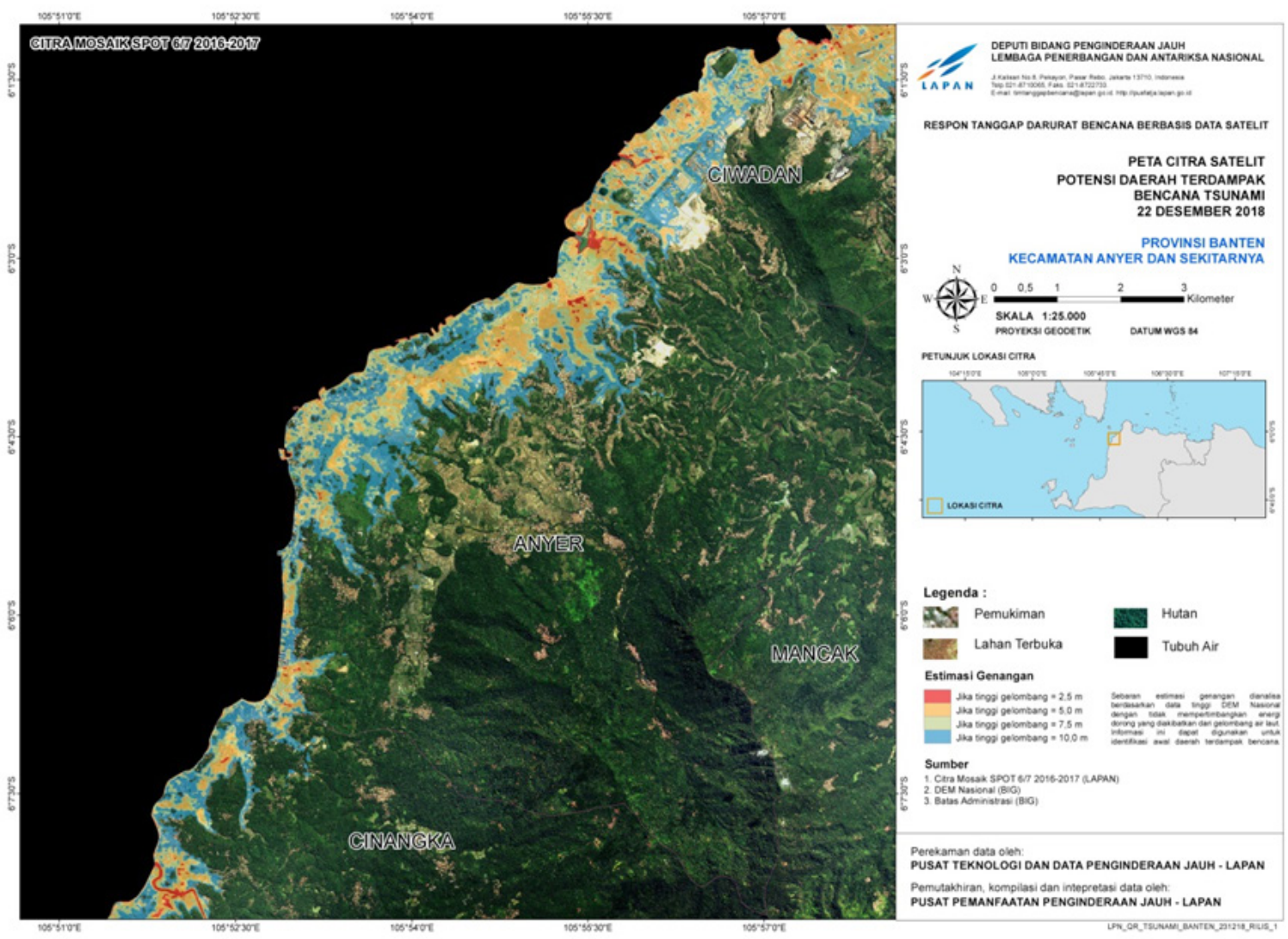

Sumber : LAPAN 
Syaiful Anwar, Agus Winarna, Priyanto -- Strategi Pemberdayaan Wilayah Pesisir Dalam Menghadapi Bencana Tsunami Serta Implikasinya Terhadap Ketahanan Wilayah (Studi di Desa Bulakan, Kecamatan Cinangka, Kabupaten Serang, Banten)

maraknya penambangan bahan galian di daerah pegunungan, sehingga air hujan tidak dapat terserap oleh tanah. Selain banjir akibat curah hujan, banjir juga diakibatkan oleh aktivitas naiknya permukaan air laut (rob). Fenomena rob yang merupakan fenomena yang ditunjukkan oleh alam, adalah akibat dari pemanasan global. Faktor pemanasan global ini juga berdampak pada naiknya tingkat curah hujan, dan meningkatnya tinggi permukaan air laut. Provinsi Banten juga memiliki ancaman metereologis dalam bentuk gerakan tanah atau tanah longsor. Beberapa wilayah, seperti Serang, Pandeglang, dan Lebak, merupakan wilayah yang masuk dalam kategori wilayah rawan tanah longsor. Cagar Alam Rawa Danau dan Kecamatan Anyer merupakan wilayah yang berada di Kabupaten Serang yang juga teridentifikasi sebagai wilayah rawan tanah longsor.

Data yang dihimpun dari Badan Penanggulangan Bencana Daerah (BPBD) Kabupaten Serang dari Januari hingga April 2019 , terdapat 5 kasus pergerakan tanah. Curah hujan dan kerentanan tanah merupakan penyebab dari adanya bencana tanah longsor. Namun berbagai bencana yang terjadi di Provinsi Banten tersebut juga dikarenakan karena kesalahan manusia setempat dalam mengelola lingkungannya. Beberapa aktivitas penambangan bahan galian mengakibatkan berbagai lereng perbukitan menjadi terbuka tanpa pepohonan sehingga memicu pergerakan tanah. Bencana abrasi juga mengancam wilayah bibir pantai Kabupaten Serang. Wilayah daratan yang terbentuk dari satuan batuan sedimen tidak padu seperti pasir, kerikilkerakal, dan lempung, sangat berpotensi terjadinya pengikisan atau abrasi. Rusaknya jalan Cigondang-Laba di Kecamatan Labuan merupakan salah satu contoh yang kasat mata akibat dari abrasi di Provinsi Banten. Bila kita ingin menempuh perjalanan ke Pembangkit Listrik Tenaga Uap (PLTU) Labuan, maka kita harus melalui ruas jalan tersebut. Penurunan permukaan tanah, hilangnya penahan vegetasi alami, dan hilangnya penahan abrasi di wilayah pesisir karena aktivitas pengerukan pasir laut, merupakan faktor-faktor penyebab adanya abrasi di wilayah Serang. Faktor penyebab lainnya, khusus untuk abrasi di wilayah pesisir utara Provinsi Banten, adalah berubahnya fungsi kawasan sempadan pantai menjadi kawasan budi daya dan industri, serta kawasan hunian.

Dalam menghadapi potensi multirawan bencana di daerahnya, Kabupaten Serang telah memiliki Peraturan Daerah (Perda) yang telah dibuat sejak tahun 2014, yaitu Perda Kabupaten Serang Nomor 4 tahun 2014 tentang Penanggulangan Bencana di Kabupaten Serang. Dengan adanya Perda ini diharapkan penanggulangan bencana di Kabupaten Serang dapat berjalan secara cepat dan tepat sasaran, yang bertumpu pada sinergitas kelembagaan antar Satuan Kerja Perangkat Daerah (SKPD) di Kabupaten Serang maupun stakeholders lainnya.

\section{Tsunami Selat Sunda pada Desember 2018}

Pada hari Sabtu malam, 22 Desember 2018, pukul 21.27, terjadi bencana tsunami yang melanda Provinsi Banten dan Provinsi Lampung, yang disebabkan oleh gelombang pasang surut yang tidak normal, karena bulan purnama, dan longsor yang terjadi di bawah laut setelah letusan gunung berapi Anak Krakatau, sehingga menimbulkan gelombang tinggi di berbagai daerah di Banten dan Lampung. Longsoran di bawah laut tersebut memicu guncangan berkekuatan magnitudo 3,4 SR. Hingga Minggu sore tanggal 23 
Gambar 2

Timeline Tsunami Selat Sunda 2018

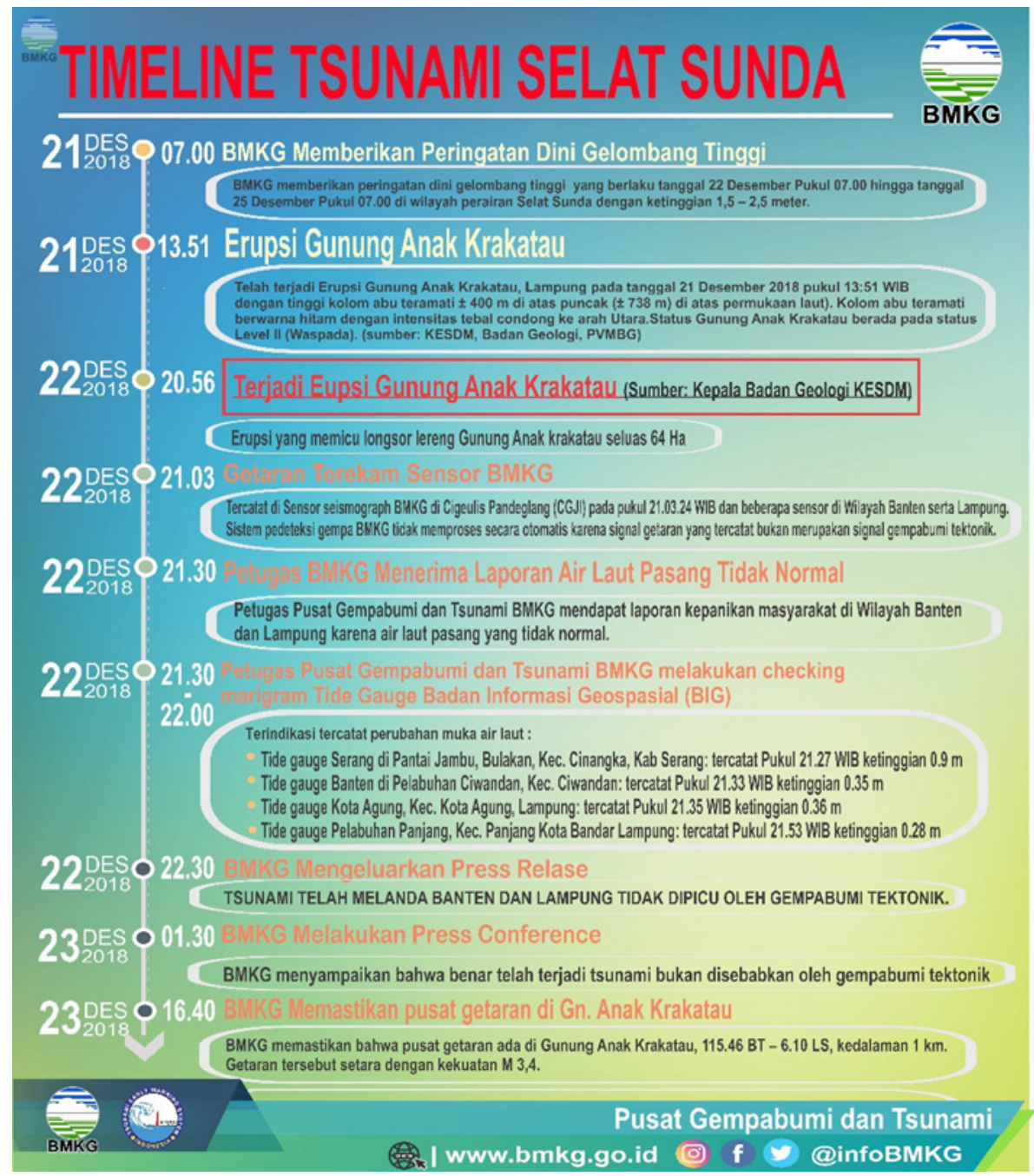

Sumber: BMKG 2018

Desember, jumlah korban tewas mencapai 222 jiwa, 843 orang terluka, dan 28 orang hilang. Sebagian besar dari korban tewas adalah para wisatawan. Kabupaten Pandeglang merupakan kabupaten yang terdampak tsunami paling parah, kemudian menyusul Kabupaten Serang (Humanity Road, 2018). Sedangkan data korban jiwa yang dirilis oleh BNPB pada Senin, 24 Desember menunjukkan 281 orang meninggal dunia, 1.016 orang terluka, dan 57 orang masih hilang, sementara jumlah pengungsi di lima kabupaten terdampak saat itu berjumlah 11.687 jiwa (BNPB, 2018).
Pusat Vulkanologi dan Mitigasi Bencana Geologi (PVMBG), dan Badan Geologi Kementerian Energi dan Sumber Daya Mineral (ESDM), sebelum terjadinya bencana Tsunami di Selat Sunda, telah berhasil mendeteksi tentang potensi adanya ancaman bahaya tersebut, khususnya tentang akan terjadinya letusan gunung Anak Krakatau Lampung. Hal ini dapat dilihat pada Gambar 2. Mereka mengamati gejala adanya semburan abu gunung yang tingginya sekitar $400 \mathrm{~m}$ di atas puncak gunung, dan $738 \mathrm{~m}$ di atas permukaan laut. Gunung tersebut pada akhirnya meletus 
Syaiful Anwar, Agus Winarna, Priyanto -- Strategi Pemberdayaan Wilayah Pesisir Dalam Menghadapi Bencana Tsunami Serta Implikasinya Terhadap Ketahanan Wilayah

(Studi di Desa Bulakan, Kecamatan Cinangka, Kabupaten Serang, Banten)

pada pukul 20.56, hari Sabtu, tanggal 22 Desember 2018, dengan mengakibatkan longsornya lereng gunung tersebut dengan luasan sekitar 64 Hektar. Sensor seismograph BMKG di Cigeulis Pandeglang (CGJ), alat sensor di Banten, dan alat sensor di Lampung juga mengamati dan tercatat kejadiannya terjadi pada jam 21.03 WIB, namun getaran tersebut tidak dapat ditangkap secara otomatis oleh BMKG setempat, karena signal getaran tersebut bukan termasuk signal gempa bumi tektonik (BMKG, 2018).

Badan Meteorologi, Klimatologi dan Geofisika (BMKG) mencatat bahwa gelombang tertinggi adalah 0,9 meter, dan tinggi gelombang berbeda-beda pada tiap titiknya. Sebagaimana diutarakan oleh Muhamad Sadly, Deputi bidang Geofisika BMKG, seperti dilansir oleh Detiknews, tinggi gelombang di Serang yang terpantau pada pukul 21.27 setinggi0,9 $\mathrm{m}$, sedangkan di Pelabuhan Ciwandar terpantau pada jam 21.33 dengan ketinggian air $90 \mathrm{~cm}$. Pada pukul 21.33 WIB, di Banten, ketinggian mencapai 0,3 m, sedangkan di Kota Agung, Provinsi Lampung ketinggian airnya $30 \mathrm{~cm}$, dan di pelabuhan Panjang ketinggian airnya adalah $28 \mathrm{~cm}$, dan terus berproses (BNPB, 2018).

Tsunami yang terjadi di perairan Selat Sunda ini berdampak pada lima kabupaten di Provinsi Banten dan Provinsi Lampung. Wilayah yang terkena dampak tsunami di Provinsi Banten adalah Pandeglang dan Serang. Wilayah Lampung Selatan, Tanggamus, dan Pesawaran, di Provinsi Lampung, adalah wilayah yang terkena dampak tsunami. Kerugian materiil yang ditimbulkan akibat tsunami di lima kabupaten tersebut yaitu 611 rumah rusak atau hancur, 69 hotel rusak, 420 perahu dan kapal hancur atau hilang, serta 60 toko rusak. Menanggapi situasi darurat tersebut, penanganan bencana telah dilakukan oleh pemerintah dan stakeholders terkait. Ada beberapa aktivitas yang terkait dengan penanganan bencana seperti mengkoordinasikan kegiatan, mengevakuasi penduduk setempat, pencarian dan penyelamatan korban bencana, menyediakan pelayanan medis, penanganan penduduk yang mengungsi dari wilayah bencana, serta perbaikan sarana prasarana umum yang rusak akibat bencana. Dalam upaya evakuasi korban, pemerintah setidaknya mengerahkan 31 alat berat. Bupati Serang sebagaimana diliput dalam tempo.co juga menginstruksikan untuk mengeluarkan cadangan ketahanan pangan di wilayahnya untuk membantu korban tsunami yang mengungsi di Kecamatan Cinangka.

Timbulnya korban jiwa dalam peristiwa tsunami Lampung dan Banten pada Desember 2018 di wilayah Serang diakibatkan karena ketidaksiapan masyarakat atau warga, sebab tsunami yang terjadi bukan akibat aktivitas tektonik sehingga tidak ada pemberitahuan dari instansi yang berwenang terkait akan terjadi gelombang tinggi akibat longsoran bawah laut gunung Anak Krakatau. Namun, upaya penanganan bencana tsunami Banten dan Lampung yang turut menerjang Kabupaten Serang berlangsung secara sistematis, cepat, dan tepat. Masing-masing instansi telah melaksanakan tugas dan fungsinya masingmasing sehingga proses evakuasi dan rehabilitasi pasca bencana dapat terlaksana dengan baik.

Desa Bulakan yang berada di pesisir pantai juga tak luput dari terjangan tsunami. Menurut data yang dihimpun oleh BPBD Kabupaten Serang, Desa Bulakan dan Desa Karangsuarga merupakan daerah terdampak paling parah dibandingkan wilayah pesisir lainnnya di Kabupaten Serang. Setidaknya 13 
orang masih dinyatakan hilang dan lebih dari 60 orang mengalami luka berat maupun ringan. Rata-rata korban merupakan wisatawan atau yang sedang berlibur diseputaran wisata pantai Anyer dan Cinangka. Sedangkan kerugian harta benda, dalam rilisnya Pemerintah Kabupaten Serang menyatakan 34 rumah dan 71 warung di Desa Bulakan ikut diterjang gelombang tsunami.

\section{Pemberdayaan Wilayah Pesisir di Desa Bulakan, Kecamatan Cinangka, Kabupaten Serang dalam Menghadapi Bencana Tsunami}

Dengan munculnya ancaman yang semakin bersifat multidimensi tersebut, maka pada akhirnya ancaman tersebut dapat memperlemah pertahanan Negara Kesatuan Republik Indonesia (NKRI). Ancaman tersebut dapat digolongkan sebagai ancaman nyata. Salah satu wujud dari ancaman nyata yang kerap melanda Indinesia adalah bencana alam. Letak strategis Indonesia dalam sirkum Ring of Fire memberikan keuntungan dengan kesuburan tanah Indonesia, namun disisi lain letak Indonesia yang dikelilingi oleh sirkum Ring of Fire menjadikan Indonesia rawan terhadap bencana, khususnya gempa bumi, tsunami, dan erupsi gunung berapi. Oleh karena itu, perlu disusun suatu sistem pertahanan negara yang memiliki keterpaduan antara pertahanan militer dan pertahanan nir-militer, yang secara utuh dibina dan dikembangkan, sehingga sampai pada tingkat kemampuan pertahanan negara yang kuat, andal, dan disegani, serta memiliki efek penangkalan yang memadai. Adapun pertahanan negara Republik Indonesia (RI) disusun dalam suatu sistem pertahanan semesta untuk mencapai tujuan nasional. Sistem pertahanan semesta merupakan upaya pertahanan yang mempunyai tiga karakteristik utama, yaitu kerakyatan, kesemestaan, dan kewilayahan. Karekteristik kerakyatan mengandung arti bahwa pertahanan negara kita diselenggarakan oleh pemerintah dan rakyat, ditujukan untuk memenuhi kepentingan seluruh rakyat Indonesia. Sedangkan ciri kesemestaan mengandung arti bahwa seluruh sumber daya, dan sarana prasarana nasional didayagunakan untuk kepentingan upaya pertahanan negara. Ciri kewilayahan berarti bahwa setiap wilayah negara di Indonesia, harus ikut serta dalam melakukan pertahanan di wilayahnya masingmasing (Kementerian Pertahanan, 2015).

Menghadapi ancaman non-militer, kementerian atau lembaga terkait menjadi komponen utama dalam usaha menanggulangi ancaman-ancaman non-militer seperti bencana alam, wabah penyakit, dan terorisme. Dalam rangka menghadapi ancaman non militer berupa bencana alam, BNPB menjadi leading sector dalam upaya cegah dini dan deteksi dini kebencanaan. BPNB melalui BPBD memiliki tugas sebagaimana diamanatkan dalam Pasal 12 dari Undang-Undang Nomor 24, Tahun 2007 tentang Penanggulangan Bencana, yaitu memberikan pedoman dan pengarahan terhadap usaha penanggulangan bencana yang mencakup pencegahan bencana, penanganan tanggap darurat, rehabilitasi, dan rekonstruksi secara adil dan setara.

Dalam hal upaya cegah dini dan deteksi dini kebencanaan bagi bencana tsunami, BPBD Banten mengajak masyarakat di pesisir khususnya didaerah yang rawan bencana tsunamai, yaitu mencanagkan Desa Bulakan dan Desa Karang Suraga menjadi desa tanggap bencana, sebagaimana diungkapkan oleh Sekretaris BPBD Serang, Nanda Bachtiar, bahwa BPBD Serang melakukan lima langkah strategi, yaitu: (i) mengajak dan 
Syaiful Anwar, Agus Winarna, Priyanto -- Strategi Pemberdayaan Wilayah Pesisir Dalam Menghadapi Bencana Tsunami Serta Implikasinya Terhadap Ketahanan Wilayah (Studi di Desa Bulakan, Kecamatan Cinangka, Kabupaten Serang, Banten)

melibatkan masyarakat untuk memetakan potensi bencana di daerahnya masing-masing, seperti menghitung jumlah penduduk yang bermukim di daerah rawan bencana tsunami; (ii) masyarakat diajak menjadi subyek dalam menghadapi bencana, dengan membuat peta tentang perencanaan penanggulangan bencana, seperti menentukan titik untuk berkumpul bagi korban bencana, lokasi untuk evakuasi, dengan pertimbangan bahwa wargalah yang lebih mengetahui medan di daerahnya; (iii) membekali kelompok masyarakat desa seperti Karang Taruna, Perlindungan Masyarakat (Linmas), sebagai relawan tanggap bencana: (iv) membuat rencana simulasi bencana yang berkelanjutan; dan (v) melatih warga untuk mempertahankan livelihood di tengah bencana.

Selain itu BNPB telah menetapkan program Desa Tangguh Bencana (Destana) kepada Desa Bulakan dan Karangsuraga, yang diartikan sebagai desa atau kelurahan yang mampu mengorganisir sumber daya masyarakat, dan sekaligus memiliki kemampuan untuk mengenali ancaman di wilayahnya. Mereka selalu membina dirinya, sehingga kapasitasnya dalam mengurangi risiko bencana selalu meningkat. Perencanaan pembangunan kemampuan tersebut mencakup hal-hal yang cukup luas, antara lain upaya-upaya pencegahan, kesiapsiagaan, pengurangan risiko bencana, serta pemulihan pasca-bencana. Dalam Destana, pihak pemerintah daerah selalu mendorong penduduk lokal untuk terlibat secara aktif dalam mengkaji, menganalisis, menangani, memantau, mengevaluasi, dan mengurangi resikobencana yang ada di wilayah mereka (Nanda Bachtiar, Komunikasi Personal, 29 Oktober 2019).

Selain itu Pemerintah Kabupaten Serang juga melakukan pemberdayaan wilayah pesisir diwilayah Desa Bulakan, Kecamatan Cinangka untuk menghadapi ancaman bencana khususnya tsunami.Pemerintah Kabupaten Serang kedepannya juga akan melakukan pemberdayaan masyarakat pesisir dengan strategi silvofishery yaitu upaya kombinasi antara pola penanaman mangrove dan usaha perikanan di desa berpotensi rawan tsunami termasuk di Desa Bulakan, Kecamatan Cinangka, Serang. Selain berbasis lingkungan, program ini juga memiliki dampak ekonomis, yaitu masyarakat dapat menjaga lingkungan sekaligus membudidayakan ikan di kawasan mangrove. Selain itu sosialisasi kesadaran bencana terus dilakukan kepada masyarakat, mengingat dalam kasus tsunami 2018 lalu diakibatkan oleh guguran material gunung Anak Krakatau dan bukan diakibatkan oleh gempa tektonik. Masyarakat pesisir khususnya nelayan juga diminta untuk menjaga dan tidak mencuri material bouy pendeteksi tsunami di laut lepas karena akan berakibat fatal bagi deteksi dini tsunami (Dikdik, Wawancara Personal, 28 Oktober 2019).

Sedangkan dalam menghadapi ancaman non-militer, Tentara Nasional Indonesia (TNI) melakukan Operasi Militer Selain Perang (OMSP). Peran TNI dalam OMSP diatur dalam Pasal 7 ayat (2) Undang-Undang Nomor 34 Tahun 2004 tentang Tentara Nasional Indonesia. Pemberdayaan wilayah pertahanan atau Dawilhan adalah salah satu manifestasi dari OMSP tersebut. Dalam rangka Dawilhan di wilayah pesisir, TNI, khususnya TNI Angkatan Darat, berpedoman pada Pasal 8 butir (e) yaitu melaksanakan Dawilhan di darat (Dawilhanrat). Hakikat Dawilhanrat adalah upaya menyiapkan wilayah pertahanan darat, dan kekuatan pendukungnya secara dini, melalui upaya membangun, memelihara, meningkatkan dan memantapkan pembinaan 
potensi wilayah darat. Penyelenggaraan Dawilhanrat merupakan suatu kegiatan pengelolaan kekayaan sumber daya nasional (Sumdanas) menjadi kekuatan pertahanan darat dalam rangka mendukung kepentingan pertahanan negara. Untuk itu diperlukan suatu tatanan atau kebijakan yang dimaksudkan untuk memandu TNI dalam mendayagunakan sumber daya nasional, dan bagaimana mekanisme koordinasi dengan Kementerian Pertahanan (Kemhan) sebagai penyelenggara fungsi Pemerintah di bidang pertahanan, serta dengan kementerian atau institusi lainnya (Bastari, 2018).

Dawilhanrat dipersiapkan melalui proses menyiapkan wilayah pertahanan beserta kekuatan pendukungnya, dan memiliki hubungan dengan penyiapan ruang, alat dan kondisi juang, melalui pembinaan dan pemberdayaan potensi kekuatan darat. Langkah selanjutnya adalah melakukan pembinaan sektor geografi dengan penyiapan ruang juang untuk kepentingan manuver pasukan dan penyiapan logistik wilayah, serta penyiapan sumber daya menjadi kekuatan pendukung yang dapat digunakan dalam upaya pertahanan negara. Selanjutnya pembinaan di bidang demografi dengan mempersiapkan alat juang yang digunakan sebagai Komponen Cadangan dan Komponen Pendukung, khususnya digelar untuk dapat mendukung Komponen Utama. Upaya pembinaan kondisi sosial dalam masa damai ditujukan untuk menyiapkan kondisi juang yang ditujukan untuk membantu Pemerintah dalam meningkatkan ketahanan wilayah melalui pemberdayaan masyarakat desa yang berdiam di wilayah pesisir.

Keterlibatan unsur TNI khususnya di wilayah teritorial Komando Distrik Militer (Kodim) 0602/Serang, sebagaimana diungkapkan oleh Komandan Kodim 0602/
Serang,bahwa dalam pemberdayaan wilayah pesisir Serang untuk menghadapi ancaman non-militer berupa bencana tsunami yaitu dengan keterlibatan Kodim 0602/Serang dalam program penanaman mangrove, dan pembuatan tanggul penahan abrasi oleh Pemda. Sedangkan upaya Dawilhanrat yang dilakukan oleh Kodim 0602/Serang adalah melakukan mitigasi dan pemetaan wilayahwilayah di daerah pesisir yang boleh dihuni dan dijadikan tempat usaha maupun yang tidak boleh dihuni karena resiko kebencanaan yang tinggi, serta upaya sosialisasi kepada masyarakat untuk menjaga daerah pesisir agar tidak terdampak abrasi. Kemudian saat pasca tsunami, TNI melalui Kodim Serang melakukan rehab yakni 39 rumah dan 251 warung. Pembangunan lima unit rumah di Desa Karang Suraga dan 34 unit di Desa Bulakan. Diantaranya ada 20 unit yang dipindahkan dari pinggiran pantai. (Mudjiharjo, Komunikasi Personal, 29 Oktober 2019).

\section{Strategi Kelembagaan dalam Pemberdayaan Wilayah Pesisir di Kabupaten Serang Dalam Menghadapi Bencana Tsunami}

Beberapa pakar secara umum sepakat bahwa yang dimaksud dengan bencana mengandung unsur ancaman (hazard), dan unsur kerentanan (vulnerability). Sedangkan ancaman secara umum diartikan sebagai fenomena, bahaya atau resiko, baik alami maupun tidak alami, yang jenisnya antara lain banjir, tanah longsor, kekeringan, wabah penyakit, konflik bersenjata, dan lain-lain. Unsur kerentanan dapat diartikan sebagai kondisi di dalam suatu komunitas yang membuat mereka mudah terkena dampak dari berbagai ancaman tersebut, yang dapat berupa kerentanan dalam hal fisik, sosial, atau kejiwaan. Untuk mengatasi kedua unsur tersebut, maka 
Syaiful Anwar, Agus Winarna, Priyanto -- Strategi Pemberdayaan Wilayah Pesisir Dalam Menghadapi Bencana Tsunami Serta Implikasinya Terhadap Ketahanan Wilayah (Studi di Desa Bulakan, Kecamatan Cinangka, Kabupaten Serang, Banten)

diperlukan upaya penanggulangan bencana, yang terdiri atas tiga tahapan, yaitu: (i) tahapan pra-bencana yang mencakup kegiatan pencegahan, mitigasi, kesiapsiagaan, serta peringatan dini; (ii) tahapan tanggap darurat (emergency response), yang ditujukan untuk meringankan penderitaan sementara, seperti kegiatan Search and Rescue (SAR), bantuan darurat, dan pengungsian; dan (iii) tahapan pasca-bencana yang mencakup kegiatan pemulihan, rehabilitasi, dan rekonstruksi, yang dimaksudkan agar kebutuhan pokok bagi korban bencana dapat dipenuhi dengan layak.

Penanggulangan ancaman bencana alam merupakan hal yang kompleks, multistakeholders, dan multi disiplin ilmu, sehingga penanganannya memerlukan kolaborasi antara pemerintah, masyarakat, dan akademisi. Penanggulangan bencana juga memerlukan terobosan dan inovasi. Upaya penanggulangan bencana melibatkan berbagai pihak, sehingga diperlukan koordinasi dan sinergi di antara mereka, khususnya dalam upaya menyiapkan sistem peringatan dini (early warning system) yang handal, serta berbagai prosedur tetap yang mudah dipahami oleh masyarakat pada umumnya. Dengan kerja sama yang erat antar kementerian, lembaga masyarakat dan instansi-instansi pemerintah lainnya, termasuk TNI, maka sistem dan prosedur yang handal, efektif, dan efisien akan dapat diwujudkan. Juga yang sangat penting adalah payung hukum bagi upaya tersebut, sehingga dapat dengan jelas dipahami tugas, tanggung jawab, serta kewenangan dari masing-masing pihak yang terlibat. Dengan aturan tersebut, maka setiap pihak akan dapat memberikan kontribusinya secara optimal.

Terkait dengan peran TNI dalam penanggulangan bencana alam dikatakan oleh Asis Wanto dari Lemhanas RI bahwa:
"Satuan komando kewilayahan dalam melakukan pemberdayaan wilayah pertahanan, memerlukan kekuatan dari unsur satuan dalam bentuk satuan cadangan di masing-masing wilayah yang siap diperbantukan untuk mempertahankan wilayahnya. Dalam kondisi damai, ancaman militer menjadi kecil kemungkinannya, maka kekuatan yang ada digunakan untuk mengatasi ancaman nir-militer yaitu dalam membantu pemerintah di daerah, diantaranya dalam penanggulangan konflik, bencana alam dan berbagai permasalahan keamanan dan pertahanan wilayah di masyarakat" (Asis Wanto, 2013).

Selain itu dengan diterbitkannya Undang-Undang Nomor 24 tahun 2007 tentang Penanggulangan Bencana, akan terbuka terobosan baru dalam hal kerjasama antar aktor dan pihak terkait, dan menyediakan payung hukum yang pasti dalam upaya penanggulangan bencana, sehingga tujuan yang telah ditetapkan, yakni penanggulangan bencana yang terpadu, terkoordinasi, dan sistematis, dapat diwujudkan. Upaya mitigasi bencana adalah unsur penting dan merupakan langkah awal dari upaya penanganan bencana, yang tujuannya adalah untuk mengurangi dampak negatif bencana. Adapun upaya ini melingkupi kegiatan-kegiatan seperti: (i) memberikan penyuluhan kepada masyarakat agar pemahamannya terhadap bahaya bencana semakin meningkat; (ii) menyusun peta wilayah rawan bencana, penghijauan hutan dan penanaman pohon bakau; dan (iii) pembangunan rumah pemukiman yang tahan gempa.

Di wilayah Kabupaten Serang, sinergi antar lembaga terjalin cukup solid antara Pemerintah Kabupaten (Pemkab), TNI, Kepolisian Republik Indonesia (Polri), serta unsur masyarakat, dalam upaya penanggulangan bencana alam khususnya 
tsunami. Sinergi yang terjalin antara Pemkab, TNI, Polri dan unsur masyarakat dalam tahap pra-bencana yang mencakup kegiatan pencegahan, mitigasi, kesiapsiagaan, serta peringatan dini, gencar dilakukan oleh stakeholders terkait. Menurut Haji Holil, tokoh masyarakat Serang yang juga tokoh dibalik pemekaran Provinsi Banten, upaya penanganan pra-bencana yang kerap dilakukan kepada masyarakat pesisir Serang antara lain: sosialisasi tanggap bencana, simulasi kebencanaan, pelatihan relawan bencana, dan penanaman bakau di pesisir pantai Serang. Hal yang sama juga diungkapkan oleh Eneng Nurcahyati, Pembina LSM GenPI Kabupaten Serang yang menyatakan bahwa BPBD Kabupaten Serang sudah sering melakukan kegitan simulasi kebencanaan dan mengajak masyarakat menentukan titik-titik kumpul jika bencana tsunami benar-benar terjadi, serta secara sistematis membangun Kampung Pesisir Tangguh Bencana bagi masyarakat di pesisir Serang salah satunya di Desa Bulakan, Kecamatan Cinangka (H. Holil dan Eneng Nurcahyati, wawancara personal 28 Oktober 2019).

Sinergi antar lembaga yang terjalin cukup solid juga ditegaskan oleh Komandan Kodim 0602/Serang, Kolonel Infanteri Mudjiharto, bahwa tahap pra-bencana yang mencakup kegiatan pencegahan, mitigasi, kesiapsiagaan, serta peringatan dini, masing masing institusi telah memiliki tugas dan fungsinya masing-masing, namun mereka perlu saling berkoordinasi dan saling berkomunikasi secara baik. Salah satu contoh upaya bersama yang telah dilakukan adalah penyusunan pemetaan rawan bencana, di mana BPBD Serang juga mengajak Kodim untuk membantu melakukan pemetaan, begitu juga sosialisasi tanggap bencana. Para Bintara Pembina
Desa (Babinsa) Kodim 0602 juga berperan dalam kegiatan sosialisasi sadar bencana bagi masyarakat pesisir Serang khususnya di empat desa yang terdampak tsunami di Kecamatan Cinangka. Saat kegiatan penghijauan pantai dengan menanam bakau yang diprakarsai oleh Pemkab Serang, Kodim 0602 juga terlibat. Begitu pula saat evakuasi tsunami 2018 lalu, Kodim 0602/Serang berkoordinasi dengan BPBD dalam penyiapan personil maupun perlengkapan yang dibutuhkan untuk evakuasi. Semuanya berjalan dengan baik tanpa ada tumpang tindih kepentingan dan wewenang, dan pada akhirnya bisa dilihat dari jumlah korban jiwa yang sedikit dan evakuasi yang berlangsung sesuai dengan prosedur (Mudjiharto, Wawancara Personal, 29 Oktober 2019).

Sebagaimana diuraikan pada bagian terdahulu bahwa Kabupaten Serang di Provinsi Banten dikategorikan sebagai daerah multirawan bencana. Potensi bencana alam di Kabupaten Serang meliputi banjir, tanah longsor, gempa bumi, abrasi pantai, dan tsunami. Pada Desember 2018 lalu, Kabupaten Serang merupakan salah satu kabupaten yang terdampak tsunami Selat Sunda disamping kabupaten tetangganya, yaitu Kabupaten Pandeglang. Kecamatan Cinangka di Kabupaten Serang merupakan wilkayah yang terdampak secara langsung, sebab empat desa diwilayah Kecamatan Cinangka langsung berbatasan dengan pantai.

Bencana alam merupakan salah satu dimensi ancaman non-militer yang nyata sebagai dampak letak geografis Indonesia. Urusan penanggulangan bencana tidak dapat dibebankan kepada satu pihak saja, dalam hal ini BNPB sebagai lembaga pemerintah nonkementerian yang diberikan mandat sebagai pelaksana penanganan bencana di Indonesia. 
Syaiful Anwar, Agus Winarna, Priyanto -- Strategi Pemberdayaan Wilayah Pesisir Dalam Menghadapi Bencana Tsunami Serta Implikasinya Terhadap Ketahanan Wilayah (Studi di Desa Bulakan, Kecamatan Cinangka, Kabupaten Serang, Banten)

Penanggulangan bencana alam merupakan tanggung jawab semua komponen bangsa, sebagaimana sistem pertahanan negara Indonesia yang bersifat semesta. Kesemestaan tersebut tentunya mengharuskan seluruh unsur kelembagaan dari tingkat nasional hingga tingkat terkecil (desa) saling bersinergi dalam upaya penanggulangan bencana (UU No 24 tahun 2007 tentang Penanggulangan Bencana).

Untuk maksud tersebut, maka seluruh unsur kelembagaan terkait perlu menyusun suatu strategi untuk menghadapi ancaman bencana tersebut. Karakteristik Desa Bulakan Kecamatan Cinangka, Kabupaten Serang yang berbatasan dengan Selat Sunda di sebelah Barat dan Laut Jawa di sebelah Utara, menjadikan Kabupaten Serang memiliki wilayah pesisir yang luas. Tentu saja ancaman bencana tsunami juga turut menghantui warga di daerah pesisir di Desa Bulakan. Strategi kelembagaan yang solid diperlukan untuk menghadapi dan menanggulangi bencana tsunami yang datang tanpa diduga. Dengan kesiapsiagaan dini, diharapkan masyarakat pesisir menjadi sadar akan ancaman bencana tsunami di wilayahnya, sehingga akan menghindarkan korban jiwa dan material saat bencana tersebutdatang.

Strategi, menurut Anthony (1999), sebagaimana dikutip oleh Nainggolan, dapat didefinisikan sebagai formulasi dari misi dan tujuan organisasi, termasuk di dalamnya adalah rencana aksi (action plans) untuk mencapai tujuan tersebut, dengan secara eksplisit menganalisis kondisi kompetisi dan pengaruh-pengaruh unsur kekuatan di luar organisasi yang berpengaruh terhadap kelangsungan organisasi, baik langsung maupun tidak langsung (Nainggolan, 2008).

Secara nasional, BNPB sebagai lembaga yang memiliki tugas dan kewenangan untuk menyusun pedoman dan pengarahan terhadap berbagai upaya yang terkait dengan penanggulangan bencana, telah menyusun Kebijakan dan Strategi Penanggulangan Bencana tahun 2015-2019. Adapun yang menjadi visi utama dalam Kebijakan dan Strategi Penanggulangan Bencana tahun 2015-2019 adalah "Menurunnya indeks resiko bencana pada pusat-pusat pertumbuhan ekonomi yang beresiko tinggi”. Dari visi tersebut kemudian diterjemahkan kedalam Arah Kebijakan dan Strategi bidang kebencanaan, yang salah satunya adalah: penurunan tingkat kerentanan terhadap bencana (BNPB, 2015).

Penurunan tingkat kerentanan terhadap bencana tersebut kemudian diterjemahkan kedalam rencana aksi, yang meliputi : (i) meningkatkan pengetahuan masyarakat tentang kebencanaan, antara lain dengan mendorong dan menumbuhkembangkan kesadaran akan bencana; (ii) melakukan penerangan kepada masyarakat melalui media yang ada untuk meningkatkan pengetahuan mereka terhadap penanganan bencana; (iii) mengembangkan kerjasama dengan negaranegara lain, mitra pembangunan, lembaga non-pemerintah, dan pihak swasta dalam penyelenggaraan penanganan bencana; (iv) melakukan percepatan rehabilitasi dan rekonstruksi wilayah yang terkena bencana agar kualitas hidup penduduk setempat segera meningkat; dan (v) meningkatkan tingkat kearifan lokal dari masyarakat dalam membangun kemampuan dan mitigasi bencana (BNPB, 2015).

Selain strategi penurunan dari tingkat kerentanan masyarakat terhadap bencana di wilayah pesisir Desa Bulakan, Kecamatan Cinangka, Kabupaten Serang untuk menghadapi resiko ancaman 
bencana tsunami juga memerlukan strategi pemberdayaan wilayah. Pemberdayaan wilayah ditujukan untuk mensinergikan strategi instansi fungsional dalam membina berbagai sumber daya yang ada, nilai-nilai, teknologi, dan dana, agar menjadi kekuatan kewilayahan yang tangguh, untuk mendukung kepentingan pertahanan. Dalam menghadapi bencana alam berupa tsunami, pemberdayaan wilayah pesisir menjadi pokok sentral dalam strategi pemberdayaan wilayah di Kabupaten Serang, tanpa meninggalkan potensi bencana alam lainnya yang kemungkinan berpotensi menimpa wilayah lain di Kabupaten Serang.

Faktor perencanaan strategis merupakan kunci pokok dari strategi kelembagaan untuk pemberdayaan wilayah pesisir di Kabupaten Serang. Rencana-rencana tersebut menunjukkan arah tujuan dari lembaga untuk mencapai sesuatu yang hendak dicapai. Secara nasional BNPB telah menyusun rencana aksi (action plan) penurunan tingkat kerentanan terhadap bencana, sedangkan BPBD Kabupaten Serang telah menerjemahkan tujuh langkah rencana aksi tersebut kedalam lima langkah aksi yang sudah dilaksanakan untuk memberdayakan wilayah pesisir Kabupaten Serang termasuk wilayah pesisir di Desa Bulakan, Kecamatan Cinangka. Penerapan lima langkah tersebut adalah: (i) mengajak dan melibatkan masyarakat untuk memetakan potensi bencana di daerah masing-masing, seperti menghitung masyarakat yang tinggal di daerah rawan tsunami; (ii) penduduk setempat didorong untuk berpartisipasi aktif dalam menghadapi bencana dengan ikut serta menyusun peta perencanaan apabila bencana terjadi, seperti menentukan titik kumpul, lokasi evakuasi, karena wargalah yang lebih mengetahui medan di daerahnya; (iii) membekali kelompok masyarakat desa seperti
Karang Taruna, Perlindungan Masyarakat (Linmas) sebagai relawan tanggap bencana; (iv) membuat rencana simulasi bencana yang berkelanjutan; dan (v) melatih warga untuk mempertahankan livelihood di tengah bencana.

Tentunya dalam melaksanakan aksi tersebut, dukungan stakeholder terkait juga menjadi penentu untuk terlaksananya program tersebut. Oleh sebab itu dukungan dari Pemerintah Kabupaten, TNI, Polri, LSM, media massa, tokoh agama, dan tokoh masyarakat, sangat diperlukan agar strategi kelembagaan dalam pemberdayaan wilayah pesisir untuk menghadapi ancaman bencana alam tsunami dapat berjalan, dan terjalin sinergitas yang baik antar lembaga dengan saling menguatkan dan mendukung. Dalam faktanya, progam yang dilaksanakan oleh BPBD Kabupaten Serang juga mendapat dukungan dari stakeholder yang berperan dalam fungsinya masingmasing. Hal ini diperkuat dengan peran Pemerintah Kabupaten dengan melaksanakan program penanaman mangrove di wilayah pesisir Serang, yang merupakan bagian dari pemeliharaan dan penataan lingkungan di daerah rawan bencana alam yang tertera dalam rencana aksi penurunan tingkat resiko bencana. Begitu juga peran TNI dan Polri, melalui Babinsa dan Babinkamtibmas di Desa Bulakan yang melakukan pemetaan jumlah Kepala Keluarga (KK) dan pemetaan daerah evakuasi serta sosialisasi dan membangun kesadaran masyarakat pesisir untuk menjaga alat deteksi dini tsunami, baik yang di tengah laut maupun yang di darat. Hal ini merupakan upaya mendorong dan menumbuhkembangkan budaya sadar bencana serta meningkatkan pengetahuan masyarakat tentang kebencanaan. Beberapa contoh di atas merupakan upaya kelembagaan untuk pengembangan wilayah 
Syaiful Anwar, Agus Winarna, Priyanto -- Strategi Pemberdayaan Wilayah Pesisir Dalam Menghadapi Bencana Tsunami Serta Implikasinya Terhadap Ketahanan Wilayah (Studi di Desa Bulakan, Kecamatan Cinangka, Kabupaten Serang, Banten)

pesisir dalam menghadapi bencana alam berupa tsunami.

Sinergi yang baik dan solid antar lembaga di Kabupaten Serang dalam pemberdayaan wilayah pesisir untuk menghadapi ancaman bencana alam tsunami diakui oleh berbagai pihak. Seperti Dandim 0602/Serang, Kolonel Inf. Mudjiharjo mengakui bahwa selama ini koordinasi antara BNPB dan Kodim Serang berjalan dengan baik dalam menghadapi situasi pra-bencana, tanggap darurat, dan pasca-bencana di Desa Bulakan, Kecamatan Cinangka, Serang. Hal tersebut juga diakui oleh Kesbangpol Kabupaten Serang melalui Kasubbag Poldagri, Bapak Dikdik yang menyatakan bahwa selama ini Pemkab selalu mengedepankan koordinasi yang baik kepada TNI, Polri dan masyarakat melalui tokoh masyarakat dalam melakukan sosialisasi pencegahan bencana di wilayah Desa Terdampak tsunami yaitu di Desa Karang Suraga dan Desa Bulakan.

Namun peneliti menemukan upaya yang telah berjalan dengan baik tersebut belum diwadahi dalam sebuah Perda yang secara spesifik mengatur tentang pemberdayaan wilayah pesisir yang berorientasi dalam bidang ketahanan wilayah untuk menghadapi ancaman non-militer dan sifat kesemestaan dalam menghadapi ancaman tersebut, meskipun saat ini telah ada Perda Kabupaten Serang Nomor 4 Tahun 2014 tentang Penaggulangan Bencana di Kabupaten Serang yang di dalamnya telah mengatur hubungan antar lembaga dalam upaya penanggulangan bencana di Kabupaten Serang sehingga.

Pemahaman unsur pemerintah daerah agar upaya di bidang ketahanan wilayah juga menjadi domain mereka nampaknya memang masih sangat rendah. Demikian juga halnya pemahaman mereka terhadap upaya Dawilhan.
Hal ini juga dicermati oleh Cecep R. Mujiono dan Armaidy Armawi dari Universitas Gajah Mada ketika melakukan penelitian di wilayah Kota Bandung. Dikatakannya bahwa beberapa kendala dalam penyelenggaraan Dawilhan di daerah antara lain: (i) Kurangnya respon pemerintah daerah terhadap pemberdayaan wilayah pertahanan; (ii) kesadaran bela negara di kalangan masyarakat pada umumnya dan kaum muda pada khususnya memang masih sangat rendah; (iii) masalah pertahanan dan keamanan dipandang seolah barang asing; (iv) secara jumlah, pakar sipil yang mendalami masalah pertahanan dan keamanan masih sangat rendah; dan (v) belum tuntasnya pembahasan RUU tentang Keamanan Nasional dan RUU tentang Komponen Cadangan sebagai pedoman bagi semua institusi yang ada maupun semua komponen bangsa, sehingga seolah-olah masalah keamanan nasional belum mendesak untuk diundangkan (Cecep R. Mujono dan Armaidy Armawi, 2011).

Dalam menghadapi bencana alam berupa tsunami, langkah yang dilakukan oleh stakeholders adalah dengan pemberdayaan wilayah pesisir yang terpadu, terintegrasi antar lembaga, dan berwawasan kepada penanggulangan bencana, yang muaranya adalah memperkuat pertahanan nir-militer dalam menghadapi ancaman non-militer berupa bencana alam. Dasar dari kemampuan masyarakat untuk menghadapi ancaman tersebut adalah karena terbangun dan terbinanya ketahanan wilayah setempat. Hal ini juga ditekankan oleh Eny Purwatiningsih dari Lemhanas RI sebagai berikut:

"Ketahanan wilayah merupakan suatu kondisi dinamik masyarakat dimana suatu wilayah dalam segala aspek kehidupannya yang terpadu meliputi 
keuletan dan ketangguhan masyarakat dalam menangkal segala ancaman, tantangan, hambatan dan gangguan terhadap identitas, integritas dari kelangsungan hidup mereka" (Eny Purwatiningsih, 2013).

Sinergi kelembagaan dalam menghadapi bencana merupakan suatu keharusan dan kewajiban bagi semua elemen bangsa. Dalam tataran pemerintahan, berbagai institusi pemerintah dilibatkan dalam penyelenggaraan penanganan bencana, baik sebagai aktor utama maupun sebagai unsur pendukung. Jumlah mereka, termasuk organisasi TNI dan Polri, adalah lebih dari 25 organisasi, di mana mereka terlibat dalam keseluruhan upaya peneyelenggaraan, yang mencakup tahapan penanganan darurat, maupun pada tahapan pemulihan pasca-bencana. Di tingkat daerah, berbagai Organisasi Perangkat Daerah (OPD) yang memiliki hubungan vertikal maupun pembinaan teknis dengan kementerian/ lembaga pemerintah pusat yang terkait, juga terlibat dalam penanganan bencana pada lingkup lokal.

Salah satu asas penanggulangan bencana yang disebutkan di dalam UndangUndang Nomor 24 Tahun 2007 tentang Penanggulangan Bencana Pasal 2 ayat (1) adalah asas kebersamaan. Asas kebersamaan bermakna bahwa penanggulangan bencana pada dasarnya adalah tugas dan tanggung jawab bersama, yang dilakukan secara gotong royong oleh Pemerintah bersama rakyat. Penanganan bencana di tingkat Provinsi maupun Kabupaten/Kota tentu saja menerapkan asas ini (UU No 24 tahun 2007).

Dalam Perda Kabupaten Serang Nomor 4 Tahun 2014 tentang Penanggulangan Bencana di Kabupaten Serang, pada pasal 22 ayat (1) terdapat dua tugas utama BPBD
Kabupaten Serang dalam tahap pra-bencana, yang selanjutnya dibagi menjadi dua kelompok kegiatan, yakni: (i) dalam situasi tidak terjadi bencana; dan (ii) dalam situasi di mana terdapat kemungkinan terjadinya bencana. Selanjutnya pasal 22 ayat (2) mengatur upaya penyelenggaraan penanggulangan bencana dalam situasi tidak terjadi bencana, yang antara lain meliputi: (i) kegiatan perencanaan untuk penanggulangan bencana; (ii) kegiatan dalam rangka mengurangi resiko bencana; (iii) upaya pencegahan bencana; (iv) upaya perencanaan pembangunan yang terpadu; (v) penyusunan beberapa persyaratan analisis resiko bagi bencana; (vi) implementasi dari rencana tata ruang yang telah ditetapkan; (vii) memberikan pendidikan dan pelatihan bagi masyarakat; dan (viii) menyusun berbagai persyaratan standar teknis dan operasional bagi penyelenggaraan penanganan bencana.

Dengan asas penanggulangan bencana yang bersifat kebersamaan, maka Pemerintah Kabupaten Serang dapat membangun sinergi dalam penanggulangan bencana khususnya potensi bencana tsunami. Penanggulangan bencana tsunami dilakukan dengan pemberdayaan wilayah pesisir di beberapa desa di Kabupaten Serang, termasuk Desa Bulakan. Upaya penanggulangan bencana dalam situasi tidak terjadi bencana harus diarahkan di wilayah pesisir. Sedangkan tanggung jawab penanggulangan bencana dalam situasi tidak terjadi bencana berada di pundak Organisasi Perangkat Daerah di Kabupaten Serang dan stakeholders yang dilaksanakan secara sinergis.

Upaya penanggulangan bencana diwujudkan dengan perencanaanyang dilakukan dengan menyusun dokumen perencanaan penanggulangan bencana sesuai dengan amanat regulasi. Dalam penanggulangan 
Syaiful Anwar, Agus Winarna, Priyanto -- Strategi Pemberdayaan Wilayah Pesisir Dalam Menghadapi Bencana Tsunami Serta Implikasinya Terhadap Ketahanan Wilayah (Studi di Desa Bulakan, Kecamatan Cinangka, Kabupaten Serang, Banten)

bencana khususnya tsunami, BPBD Provinsi Banten telah merilis potensi gelombang tsunami di Kabupaten Serang, selain itu BPPT juga telah membuat pemetaan model simulasi gelombang yang menerjang pesisir Serang bila terjadi gempa tektonik di dasar laut. Pengurangan resiko bencana, dilakukan dengan membekali kelompok masyarakat desa Bulakan seperti Karang Taruna, Perlindungan Masyarakat (Linmas) sebagai relawan tanggap bencana, dan membentuk desa tangguh bencana. Hal ini mendapat sambutan baik dari tokoh masyarakat setempat, sebagaimana diungkapkan oleh H. Sanusi, tokoh masyarakat Serang bahwa program relawan tanggap bencana mendapat tanggapan yang positif dari masyarakat pesisir Serang. Selain melakukan pelatihan relawan tanggap bencana, tindakan pengurangan resiko bencana dilakukan dengan penanaman pohon bakau di pesisir Serang dengan melibatkan stakeholders diantaranya TNI, Polri, LSM, pelajar dan masyarakat pesisir sendiri. Pencegahan, dilakukan dengan pemasangan perangkat Early Warning System (EWS) di pesisir Cinangka, Serang. Tindakan selanjutnya adalah memberikan edukasi dan sosialisasi kepada masyarakat untuk menjaga perangkat EWS dengan tidak merusak atau membongkar perangkat EWS yang telah terpasang. Hal ini diungkapkan oleh Sekretaris BPBD Serang bahwa masyarakat perlu diedukasi tentang pentingnya alat EWS yang terpasang di pantai Cinangka, sebab bila masyarakat tidak paham pentingnya alat tersebut maka akan jatuh korban bila tsunami menerjang pesisir Cinangka (Wawancara personal, 29 Oktober).

Pemaduan dalam perencanaan pembangunan yang beroroientasi kepada ketahanan wilayah khususnya di Desa Bulakan, Kecamatan Cinangka, ternyata belum dilaksanakan karena belum diadopsinya kajian kebencanaan yang dibuat BPBD Kabupaten Serang oleh OPD lainnya karena kurangnya sosialisasi. Persyaratan analisis resiko bencanadilakukan dengan penyusunan kajian resiko bencana. Pelaksanaan dan penegakan rencana tata ruang, di mana kegiatan ini juga belum dilaksanakan karena belum adanya permintaan koordinasi dari Dinas Penataan Ruang Kabupaten Serang. Saat ini kebanyakan wilayah pesisir termasuk di pesisir Desa Bulakan telah dimanfaatkan untuk usaha hotel/resort.

Dalam hal pendidikan dan pelatihan, BPBD Kabupaten Serang telah melakukan gladi dan simulasi bencana tsunami dengan melibatkan unsur masyarakat, TNI, Polri, dan SKPD lain di Kabupaten Serang. Gladi dan Simulasi juga kerap dilakukan oleh BPBD Provinsi Banten. Hal ini diungkapkan oleh Sekretaris BPBD Serang, bahwa pasca-tsunami 2018 lalu, BPBD Serang kerap mengadakan gladi dan simulasi bencana tsunami, baik yang dilakukan di lingkup Kabupaten maupun Provinsi. Namun kegiatan gladi dan simulasi tsunami ini belum dapat dilakukan di semua daerah pesisir Serang akibat keterbatasan sumber daya yang dimiliki BPBD Serang. Persyaratan standar teknis penanggulangan bencana, di mana standar teknis penanggulangan bencana berupa rencana kontijensi di tingkat Kabupaten, belum dibuat oleh BPBD Kabupaten Serang.

Strategi pemberdayaan wilayah pesisir dalam bentuk sinergi kelembagaan di Kabupaten Serang dalam menghadapi ancaman bencana alam tsunami di wilayah pesisir Desa Bulakan, Kecamatan Cinangka merupakan bentuk implementasi aspek ketahanan nasional dalam bidang pertahanan dan keamanan dalam kondisi kehidupan 
nasional Indonesia. Wujud ketahanan tersebut tercermin dalam kondisi upaya daya tangkal bangsa dalam menghadapi ancaman nir-militer beruapa bencana alam yang dilandasi oleh kesadaran bela negara untuk memelihara stabilitas pertahanan dan keamanan yang dinamis. Aspek pertahanan dan keamanan yang optimal harus mampu mewujudkan kesiapsiagaan, kemampuan, dan kekuatan melalui Sishanta. Sinergitas antar lembaga mengahadapi ancaman bencana tsunami di Kabupaten Serang merupakan upaya pelaksanaan Sishanta dalam menghadapi ancaman nirmiliter berupa bencana alam.

Upaya penanganan bencana, dengan segala tahapannya, perlu mengikutsertakan berbagai institusi pemerintah dan juga kelompok-kelompok masyarakat sipil, serta pihak swasta. Diperlukan upaya bersama yang sinergik dari para peserta tersebut, agar upaya tersebut dapat berhasil guna. Langkah sinergi tersebut perlu dibina dan ditingkatkan secara terus menerus agar kemampuan untuk mengurangi resiko bencana, mendeteksi kapan terjadinya bencana, maupun melakukan upayaupaya mitigasi bencana sedini mungkin, dari hari ke hari terus meningkat, dan hambatan yang sering menghadang pelaksanaan penanganan bencana selama ini semakin dapat diminimalisir.

Peningkatan kesadaran masyarakat pesisir Desa Bulakan, Kecamatan Cinangka, Serang merupakan hal yang paling penting untuk ditingkatkan dalam penanggulangan bencana, dengan melakukan berbagai upaya agar sejak dini anggota masyarakat memilikinya. Upaya pembinaan tersebut perlu dilakukan di berbagai lingkungan masyarakat, seperti sekolah, tempat mereka bekerja, di pemukiman penduduk, serta tempat berinteraksi sosial lainnya. Upaya sosialisasi dan pembimbingan kepada masyarakat perlu dilakukan oleh Pemerintah, dengan maksud agar mereka sadar bahwa wilayah tempat kita hidup ini adalah wilayah yang sangat rawan terhadap bencana, dan bencana tersebut dapat datang kapan saja, di mana saja, dan dapat menimpa siapa saja.

Tsunami yang melanda Provinsi Banten dan Provinsi Lampung pada Desember 2018 menyadarkan banyak pihak betapa pemberdayaan wilayah pesisir untuk menghadapi ancaman nyata berupa bencana alam merupakan hal yang segera dilakukan. Pemberdayaan wilayah pesisir dalam menghadapi bencana alam berupa tsunami tidak hanya menjadi tanggung jawab satu pihak saja. Undang-Undang mengamanatkan bahwa penanggulangan bencana alam harus berasaskan kebersamaan, yang bermakna bahwa penanggulangan bencana pada dasarnya adalah tugas dan tanggung jawab bersama antara Pemerintah dan masyarakat.

Bila ditinjau dalam teori manajemen, maka penyelenggaraan penanggulangan bencana mengandung beberapa kegiatan, yakni: merencanakan, mengorganisasikan, melaksanakan, dan pengawasan terhadap keseluruhan upaya tersebut. Upaya tersebut juga sama seperti halnya dengan upaya manajemen yang lingkupnya mengatur berbagai input, yakni: manusia, uang, metode, mesin, pasar, material, dan informasi. Semua input tersebut saling berkaitan dan menjadi faktor dominan dalam mempengaruhi implementasi kebijakan mengenai sinergitas kelembagaan untuk pemberdayaan wilayah pesisir di Kabupaten Serang dalam menghadapi bencana tsunami.

Sebagaimana yang diungkapkan oleh Edward, ada empat variabel yang menentukan keberhasilan suatu sinergi yaitu: komunikasi 
Syaiful Anwar, Agus Winarna, Priyanto -- Strategi Pemberdayaan Wilayah Pesisir Dalam Menghadapi Bencana Tsunami Serta Implikasinya Terhadap Ketahanan Wilayah (Studi di Desa Bulakan, Kecamatan Cinangka, Kabupaten Serang, Banten)

antar peserta, sumber daya yang dialokasikan, disposisi dari masing-masing peserta, dan struktur birokrasi yang mewadahi para peserta tersebut.Saat ini pelaksanaan pemberdayaan wilayah pesisir di Kabupaten Serang dapat terlaksana dengan baik, antar Pemerintah Kabupaten, BPBD Kabupaten Serang, TNI, Polri, LSM, dan civil society di wilayah pesisir Kabupaten Serang. Adapaun faktor yang paling dominan dalam sinergitas kelembagaan dalam pemberdayaan wilayah pesisir Serang dalam menghadapi ancaman bencana alam berupa tsunami adalah dukungan dari masyarakat dan terjalinnya komunikasi dan koordinasi yang baik antar stakeholder.

Dukungan masyarakat wilayah pesisir Desa Bulakan terlihat dengan antusiasme masyarakat terhadap program pemberdayaan wilayah pesisir yang dilakukan oleh berbagai pihak. Seperti BNPB dengan pelatihan relawan tanggap bencana, dan pelaksanaan simulasi penanganan bencana tsunami. Antusiasme masyarakat terhadap program BPBD Serang sangat tinggi karena masyarakat juga dilibatkan sebagai subyek penanggulangan bencana seperti memberikan kesempatan bagi kearifan lokal dalam penanggulangan bencana tsunami, menentukan lokasi yang akan digunakan sebagai titik kumpul dan lokasi evakuasi. Begitu juga dengan program penanaman pohon bakau yang dicanangkan oleh Pemerintah Kabupaten Serang yang akan dikembangkan menjadi silvofihery yaitu budidaya perikanan berbasis lahan bakau, sehingga selain menjaga wilayah pantai dari terjangan tsunami maupun gerusan abrasi, warga pesisir dan nelayan juga mendapat nilai tambah secara ekonomi.

Komunikasi yang baik antar stakeholders juga menjadi faktor yang mempengaruhi terselenggaranya strategi pemberdayaan wilayah pesisir Kabupaten Serang. Komunikasi yang baik menjadi langkah awal kesuksesan dari kerjasama yang ada dalam menggerakkan berbagai sumber daya yang tersedia untuk penanggulangan bencana yang terjadi. Dengan komunikasi yang baik dalam keseluruhan upaya penanganan, mulai dari membuat kebijakan, rencana, rencana aksi, hingga memonitor dan mengevaluasi upaya penanganan di daerah tersebut. Namun komunikasi dan koordinasi perlu ditingkatkan oleh BPBD Kabupaten Serang kepada OPD di wilayah Kabupaten Serang seperti Dinas Tata Ruang dan Tata Wilayah, agar pelaksanaan dan penegakan rencana tata ruang berbasis kewaspadaan bencana tsunami dapat dilaksanakan. Begitu juga komunikasi kepada pelaku usaha hotel dan resort di wilayah pesisir Kabupaten Serang perlu ditingkatkan untuk meningkatkan kewaspadaan terhadap resiko bencana tsunami.

\section{SIMPULAN}

Berdasarkan analisis data tentang berbagai hal yang menyangkut objek penelitian, selanjutnya dapat diambil beberapa kesimpulan sebagai berikut:

Pertama, Desa Bulakan, Kecamatan Cinangka, Kabupaten Serang merupakan salah satu desa terdampak tsunami Selat Sunda terparah. Diperlukan strategi bersama perlu dilakukan untuk mengurangi dampak resiko bencana tsunami di Kabupaten Serang khususnya di Desa Bulakan, Kecamatan Cinangka, dengan langkah pemberdayaan wilayah pesisir dalam rangka menghadapi ancaman nyata, berupa bencana tsunami. Pemerintah Kabupaten Serang telah melakukan serangkaian strategi yang tertuang dalam rencana aksi penanggulangan bencana tsunami berbasis pemberdayaan wilayah pesisir yang 
mengajak dan melibatkan masyarakat untuk memetakan potensi bencana di daerah masingmasing, seperti menghitung masyarakat yang tinggal di daerah rawan tsunami.

Kedua, pelaksanaan strategi pemberdayaan wilayah pesisir di Desa Bulakan Kecamatan Cinangka, Kabupaten Serang dalam menghadapi ancaman bencana tsunami diperlukan suatu sinergi kelembagaan agar strategi yang dijalankan berdampak luas bagi masyarakat di wilayah pesisir. Dalam menjalankan strategi tersebut, Pemkab Serang berpedoman pada Perda Nomor 4 tahun 2014 tentang Penanggulangan Bencana di Kabupaten Serang, Pasal 22 ayat (2) Penyelenggaraan penanggulangan bencana dalam situasi tidak terjadi bencana yang meliputi: perencanaan penanggulangan bencana, pengurangan resiko bencana, pencegahan, pemaduan dalam perencanaan pembangunan, persyaratan analisis resiko bencana, implementasi dari rencana tata ruang yang telah ditetapkan, pendidikan dan pelatihan, serta berbagai persyaratan standar teknis dan operasional dalam hal penanganan bencana sehingga program pemberdayaan masyarakat pesisir tersebut dapat mengutakan ketahanan wilayah di Desa Bulakan dalam menghadapi ancaman bencana lainnya di masa mendatang.

Ketiga, faktor yang mempengaruhi pelaksanaan strategi pemberdayaan wilayah pesisir di wilayah Desa Bulakan, Kabupaten Serang untuk ketahanan wilayah adalah dukungan masyarakat dan komunikasi yang baik antar stakeholders. Komunikasi yang baik menjadi langkah awal kesusksesan strategi koordinasi dan komando, yang digunakan untuk memobilisasi seluruh sumber daya penanggulangan bencana yang tersedia. Dalam pemberdayaan wilayah pesisir, komunikasi dan koordinasi antara unsur Pemkab, BNPB, TNI, Polri dan masyarakat telah terjalin cukup baik. Namun komunikasi dan koordinasi pada tataran pelaku usaha, khususnya pelaku usaha pariwisata, dan beberapa unsur OPD seperti Dinas Tata Ruang dan Wilayah, khususnya koordinasi mengenai pemetaan daerah rawan bencana di pesisir, belum berjalan cukup baik.

Selanjutnya, saran dari peneliti yaitu agar BPBD Kabupaten Serang perlu menerbitkan rencana kontijensi daerah dalam menghadapi ancaman bencana tsunami dan segera menyusun Perda pemberdayaan wilayah pesisir. Dengan adanya Perda pemberdayaan wilayah pesisir dan Rencana Kontijensi tsunami di Kabupaten Serang, maka sinergi kelembagaan pemberdayaan wilayah pesisir di Kabupaten Serang akan semakin kuat.

\section{DAFTAR PUSTAKA}

Badan Nasional Penanggulangan Bencana \& JICA. (2009). Kajian tentang Penanggulangan Bencana Alam di Indonesia. Jilid 2.Asian Disaster Reduction Center.

Badan Nasional Penanggulangan Bencana. (2015). Kebijakan dan Strategi Penanggulangan Bencana 2015-2019. Jakarta:BNPB

Badan Pusat Statistik. (2018). Kabupaten Serang dalam Angka. Serang: Badan Pusat Statistik Kabupaten Serang.

Bastari, Achmad. (2018). "Strategi Pemberdayaan Wilayah Pertahanan Laut dalam Meningkatkan Kesadaran Bela Negara di Kabupaten Tangerang, Banten (Studi Di Lantamal III/Jkt)". Jurnal Prodi Strategi Perang Semesta, Desember 2018, Volume 4, Nomor 3

BPBD Provinsi Banten (2010). Rencana Kontijensi Kota Cilegon Dalam 
Syaiful Anwar, Agus Winarna, Priyanto -- Strategi Pemberdayaan Wilayah Pesisir Dalam Menghadapi Bencana Tsunami Serta Implikasinya Terhadap Ketahanan Wilayah (Studi di Desa Bulakan, Kecamatan Cinangka, Kabupaten Serang, Banten)

Menghadapi Ancaman Gempa Bumi dan Tsunami 2010. Banten: BPBD Banten.

Coulter, Mary. (2007). Management, Ninth Edition. New York: Pearson Prentice Hall.

Creswell.J. (2010). Qualitative Inquery and Research Design: Choosing Among Five Traditions. CA: Sage, Thousand Oaks. Humanity Road. (2018). "Laporan Tsunami Provinsi Banten Indonesia”. Jakarta, Humanity Road Indonesia

Iskandar. (2009). Metodhologi Penelitian Kualitatif. Jakarta: Gaung Persada Press. LAPAN. (2018). Respon Tanggap Darurat Bencana Berbasis Data Satelit. Jakarta: LAPAN.

Miles, M. B. Huberman, A. M. (2007). Qualitative Data Analiysis: An Exspanded Sourcebook. Beverly Hills: Sige Publications.

Moleong, Lexy J (2004). Metodologi Penelitian Kualitatif. Bandung: Remaja Rosda Karya.

Mulyadi, Dedi, et.all. (2015). Penataan Ruang Berdasarkan Kebencanaan di Daerah Kabupaten Pandeglang. Pemaparan Hasil Penelitian Geoteknologi 2015. Jakarta: Lembaga Ilmu Pengetahuan Indonesia

Paidi. (2012). "Pengelolaan Manajemen Resiko Bencana Alam di Indonesia”. Jurnal Widya, Tahun 29, Nomor 321 Juli - Agustus.

Sekretariat Negara RI. (2014). Membangun Sinergi antar Multistakeholder dalam Menghadapi Ancaman Bencana
Hidrologi di Indonesia”. Jakarta: Kementerian Sekretariat Negara RI.

Sjafari, Agus, et.all. (2018). "Model Pemberdayaan Ekonomi Masyarakat Pesisir Di Provinsi Banten: Study Kasus Di Desa Lontar Kecamatan Tirtayasa, Kabupaten Serang Dan Desa Citeurep, Kecamatan Panimbang, Kabupaten Pandeglang”.Jurnal Pembangunan Kebijakan Daerah, Volume 2, No. 1 tahun 2018

Solaeman, M. Khifni. Et.all. (2012). Pemetaan Multirawan Bencana di Provinsi Banten. Jurnal Globe Vol. 14. No. 1 Juni 2012. Jakarta: Badan Informasi Geospasial.

Subagyo, Agus \& Rusfiana, Yudi (2018). Sinergi TNI Angkatan Darat Dengan Pemerintah Daerah dalam Penanggulangan Bencana Alam (Studi Kasus di Kabupaten Badung Provinsi Bali). Jurnal Transformasi, Universitas Jenderal Ahmad Yani, Vol. 10 No. 2, Oktober 2018.

\section{Peraturan Perundang-Undangan}

Undang-Undang Nomor 34 Tahun 2004 tentang Tentara Nasional Indonesia.

Undang-Undang Nomor 24 Tahun 2007 tentang Penanggulangan Bencana.

Perda Kabupaten Serang No 4 Tahun 2014 tentang Penanggulangan Bencana di Kabupaten Serang.

Wawancara:

1, Asis Wanto dari Lemhanas RI, 2013

2 Eny Purwatiningsih, Lemhanas RI 2013 